\title{
Strategi Model Bisnis UMKM Kuliner Untuk Bertahan di Era COVID-19
}

\author{
Richa Nahdalaily Fathara ${ }^{1}$, Muhamad Rizal ${ }^{2}$, Ria Arifianti ${ }^{3}$, Asmaul Husna ${ }^{4}$ \\ ${ }^{123}$ Universitas Padjadjaran, Bandung, Jawa Barat, Indonesia \\ ${ }^{4}$ Universitas Maritim Raja Ali Haji, Tanjung Pinang, Kepulauan Riau, Indonesia
}

\begin{abstract}
ABSTRAK : Penelitian ini bertujuan untuk mendeskripsikan strategi model bisnis dengan pendekatan Business Model Canvas yang dapat diterapkan pada UMKM agar dapat bertahan pada pandemi COVID-19 . Penelitian ini menggunakan metode analisis deskriptif dengan menggunakan metode pendekatan kualitatif. Data yang dikumpulkan merupakan data primer yaitu berupa hasil wawancara. Hasil dari penelitian ini memberikan deskripsi dari strategi model bisnis yang dipaparkan dengan menggunakan tools Business Model Canvas (BMC) untuk UMKM agar mampu bertahan di era COVID-19. Sembilan blok dari BMC ini menunjukkan bahwa setiap elemen BMC saling berkaitan dan harus dianalisis secara menyeluruh secara rinci dalam mencapai ketahanan bisnis. Strategi model bisnis diperlukan dalam pencapaian tujuan bisnis dan pengembangan produk UMKM agar lebih kompetitif dan dapat bertahan di era COVID-19. Penggunaan bisnis model yang tepat akan membuat UMKM dapat mencapai ketahanan bisnis.
\end{abstract}

Kata kunci: Model Bisnis; Bisnis Model Kanvas; Ketahanan Bisnis; COVID-19 ; UMKM

\begin{abstract}
The purpose of this study is to describe the business model innovation with the Business Model Canvas approach that can be applied to MSMEs during the COVID-19 pandemic so that MSMEs can survive (business resilience). This research uses a qualitative method, with literature studies accessed from several sources, both print and electronic media, books, and research results from various electronic journals. The data analysis used is descriptive analysis. The description of the business model innovation is presented using the Business Model Canvas (BMC) tools. The nine blocks of BMC are important elements that must be thoroughly analyzed in detail in order to achieve business resilience. A business model strategy is needed in achieving business goals and developing SME products so that they are more competitive and can survive in the pandemic era. The use of the right business model will result in MSMEs being able to achieve business resilience.
\end{abstract}

Keywords: Business Model, Business Model Canvas, Business Resilience, COVID-19, MSMEs

Email Address : richa16001@mail.unpad.ac.id ${ }^{1}$, muhamad.rizal@unpad.ac.id², asmaulhusna@umrah.ac.id ${ }^{4}$

\section{Pendahuluan}

Coronavirus 2019 (COVID-19) yang berasal dari Wuhan, China pada Desember 2019 telah menyebar secara global ke lebih dari 200 negara termasuk Asia, Eropa, Amerika dan Australia. Wabah ini telah dikategorikan sebagai pandemi oleh Organisasi Kesehatan Dunia (WHO, 2019) karena menunjukkan infeksi antar manusia (Qiu et al., 2017; Zhou et al., 2018) yang menyebabkan lebih dari 200.000 angka kematian dalam waktu tiga bulan sejak awal adanya wabah (WHO, 2020). Pandemi COVID-19 berada pada tingkat infeksi dan kematian tertinggi dibandingkan dengan wabah virus korona lainnya seperti MERS-CoV, SARSCoV, dan Influenza (Acter et al., 2020; Peeri et al., 2020)

Literatur sebelumnya berpendapat bahwa 
pembatasan mobilitas menjadi salah satu langkah efektif yang harus dilakukan dalam mengendalikan penyebaran penyakit menular seperti virus COVID-19 (Anzai et al., Chauhan et al., 2020). Berkaitan dengan hal ini, beberapa negara sudah memberlakukan pembatasan baik dalam keperluan perjalanan, sosial, dan acara termasuk negara Asia Tenggara, seperti Indonesia. Perintah pembatasan atau karantina yang bertujuan untuk mencegah penyebaran virus corona ini tidak hanya menimbulkan dampak psikologis seperti depresi, kecemasan dan stres (Ozamiz, 2020) tetapi juga berpengaruh pada kegiatan ekonomi seperti tindakan penutupan lokasi-lokasi usaha dan pembatasan pengiriman produk (Inoue \& Todo, 2020; Karabag, 2020). Seperti yang terjadi di Indonesia, 14 hari karantina wilayah yang dimulai sejak Maret 2020 telah mengganggu pengoperasian beberapa sektor penting, termasuk pangan, ritel, transportasi, dan sektor pariwisata (Hadiwardoyo, 2020).

Sebelum fokus pada dampak dan strategi untuk mengurangi dampak, dibutuhkan pemahaman yang mendasar terkait konsep dan definisi krisis. krisis. Menurut Booth (1993), krisis merupakan sebuah keadaan yang dihadapi oleh individu, kelompok atau organisasi dimana keadaan tersebut tidak dapat diatasi dengan menggunakan prosedur normal yang terjadi rutin. Krisis merupakan rangkaian peristiwa yang dapat memiliki konsekuensi negatif yang substansial bagi organisasi jika tidak dikelola dengan baik (Jaques, 2007; Williams et al., 2017; Pedersen et al., 2020) telah menjadi sumber peluang sepanjang sejarah manusia (Bernstein, 1996; Chisholmburns, 2010; Goffin \& Mitchell, 2010). Dampak wabah pandemi COVID-19 pada sosial ekonomi dapat menjadi akut, dan sangat penting untuk melakukan pemulihan dari keadaan tersebut. Namun, sedikit yang diketahui tentang tantangan tersebut dan bagaimana strategi model bisnis UMKM dalam merespons krisis wabah COVID-19.

Namun, terlepas dari pentingnya krisis untuk perubahan model bisnis, sebagian besar literatur telah mengabaikan peran krisis dalam mendorong inovasi model bisnis (Johnson \&
Lafley, 2010; Morris, 2010; Foss \& Saebi, 2015; Gorissen \& Manshoven, 2016). Pengetahuan yang masih terbatas tentang topik ini menjadi penting pada era pandemi COVID-19 saat ini. Hal ini dikarenakan banyak bisnis yang tiba- tiba menemukan jati diri mereka membutuhkan adaptasi model bisnis yang substansial (Kuckertz et al., 2020; Ritter \& Pedersen, 2020). Peneliti berusaha untuk mengatasi kesenjangan ini dalam literatur, dan memberikan panduan praktis yang bersifat saran bagi pelaku bisnis saat ini khususnya UMKM bidang kuliner.

Pemilihan UMKM dalam penelitian ini sebagai fokus utama dalam strategi manajemen krisis, dikarenakan UMKM merupakan sektor yang paling penting dalam perekonomian Indonesia. Menteri Koperasi dan UKM Teten Masduki, menjelaskan bahwa UMKM memiliki peranan dan kontribusi yang sangat besar dalam perkenomian nasional. Dimana terdapat lebih dari 64 juta unit UMKM berkontribusi 97 persen terhadap total tenaga kerja dan 60 persen PDB nasional. Oleh sebab itu, jika UMKM mengalami dampak dari COVID-19 ini, hal ini tentu akan berdampak besar juga terhadap perekonomian nasional (Kementerian Koperasi dan UMKM, 2020). Salah satu dampak tersebut adalah terjadinya penurunan omzet yang terjadi pada pelaku UMKM (Milzam et al., 2020). Hal ini dikarenakan berbagai pembatasan yang diberlakukan sehingga pelaku UMKM mengalami penurunan jumlah konsumen dan menjadi sektor yang paling rentan mengalami krisis ekonomi.

Sebelum terjadinya pandemi COVID-19, Sejarah perekonomian Indonesia mencatat kontribusi UKM dalam menghadapi berbagai krisis, sebagai contoh pada saat krisis moneter tahun 1998. Pada saat krisis tersebut, UKM tetap kuat menjadi penyangga perekonomian nasional. Namun saat ini, sektor UKM akan menjadi sektor yang paling rentan terhadap krisis ekonomi akibat COVID-19 , karena ini UMKM bergantung kepada perputaran uang dari penjualan barang dagangan.

Jika dampak COVID-19 terhadap UMKM tidak segera tertangani, UMKM diprediksi akan semakin parah. Terlebih, resesi 
yang sangat mungkin terjadi, akan menjadi tidak bisa dihindari. Seberapa lama resesi ini akan bergantung kepada kebijakan-kebijakan dalam mengatasi kasus COVID-19, mengatasi likuiditas masalah UMKM, kebijakan dalam mendukung keluarga yang mengalami kesulitan keuangan, dan kebijakan untuk pekerjaan yang terjamin, dan jaminan rantai pasokan juga menjadi pertimbangan penting (Fernandes, 2020).

Sebuah perusahaan akan dapat bertahan terhadap krisis tersebut jika dapat memanfaatkan peluang yang terdapat pada krisis tersebut untuk menemukan cara perusahaan mengalami pertumbuhan yang efisien. Salah satu langkahlangkah yang dapat diambil dalam menghadapi tantangan tersebut adalah melakukan restrukturisasi/inovasi model bisnis. Inovasi model bisnis merupakan sebuah alat yang penting dalam membangun bisnis yang menciptakan nilai optimal untuk semua pemangku kepentingan baik pelanggan, pemegang saham, karyawan, dan masyarakat besar (Baghiu, 2020). Hal ini dikarenakan mengantisipasi perubahan masa depan dalam lingkungan bisnis sangat penting dilakukan (Ojasalo et al., 2018). Hal ini juga erat kaitannya dengan langkah transformasi digital yang diperlukan dalam melakukan inovasi model bisnis di era COVID-19. Transformasi digital bukan hanya berarti memperkenalkan teknologi baru untuk melakukan kegiatan yang ada, akan tetapi merupakan proses mendesain ulang seluruh model bisnis (Casalino et al., 2019). Pendekatan tiga semacam ini menciptakan beberapa manfaat atau peluang diantaranya peningkatan penciptaan nilai akan menyebabkan peningkatan pertumbuhan, karena akan menjadi lebih sulit untuk ditiru oleh pesaing, memperkuat keunggulan kompetitif akan berlangsung dalam periode yang lebih lama dan dapat membuat bisnis lebih mampu bertahan terhadap pasar siklus dan peristiwa "black swan" yang tidak terduga, seperti krisis COVID-19 yang terjadi baru-baru ini.

Kurangnya penelitian tentang inovasi model bisnis sebagai cara UMKM bertahan dan berkembang di era COVID-19, sehingga penelitian ini difokuskan menganalisis strategi model bisnis yang dirancang agar UMKM dapat bertahan dan berkembang di era COVID menggunakan tools business model canvas dan menguraikannya ke dalam elemen-elemen business model canvas. Penulis memanfaatkan teori dan penelitian yang telah ada untuk mengidentifikasi dan memetakan komponen kunci model bisnis. Hal ini bertujuan untuk memetakan strategi-strategi bertahan di era COVID-19 agar lebih praktis digunakan oleh para UMKM dalam menyusun konsep model bisnis.

Konsep model bisnis telah didefinisikan dengan berbagai cara. Mason dan Spring (2011, p.1033) menyimpulkan bahwa "sebagian besar penelitian model bisnis telah menggambarkan model bisnis sebagai deskripsi tentang bagaimana bisnis dilakukan (Chesbrough \& Rosenbloom, 2002; Hedman \& Kalling, 2003; Baden \& Morgan, 2010) dengan mengidentifikasi elemen atau komponen yang mendasari model bisnis itu' (Fielt, 2013).

Penjelasan bisnis model tersebut memberikan penjelasan yang luas terkait elemen penting (Osterwalder \& Pigneur, 2010), namun masih terdapat keterbatasan dalam menentukan bagaimana elemen- elemen tersebut dihubungkan. Namun, keberhasilan bisnis bisa dibilang didefinisikan dengan menghubungkan dimensi aliran yang efisien dari input melalui proses transformasi dan output yang ditawarkan ke pelanggan.

Osterwalder \& Pigneur (2010) mendefinisikan model bisnis adalah sebuah pemikiran yang menggambarkan tentang bagaimana sebuah organisasi melakukan tindakantindakan dalam menciptakan dan menawarkan nilai-nilai kepada pelanggan. Kemudian Osterwalder \& Pigneur (2010) menjelaskan BMC merupakan sebuah tools yang terdiri dari 9 blok elemen-elemen bisnis sebagai berikut:

- Segmen pelanggan: Menjelaskan kelompok atau organisasi yang ditargetkan oleh perusahaan.

- Saluran: Menjelaskan bagaimana perusahaan berkomunikasi dan menjangkau segmen pelanggannya.

- Hubungan pelanggan: Menjelaskan bagaimana jenis hubungan yang dibangun perusahaan 
dengan segmen pelanggan yang ditargetkan.

- Proposisi nilai: Menjelaskan bagaimana produk dan layanan diciptakan dengan berbagai nilai-nilai yang ditawarkan untuk segmen pelanggan yang spesifik. Proposisi nilai dapat mencakup karakteristik seperti inovasi, kinerja, desain, merek / status, harga, dan lain sebagainya.

- Aliran pendapatan: Menjelaskan bagaimana pendapatan yang dihasilkan perusahaan dari setiap segmen.

- Sumber daya utama: Menjelaskan aset terpenting yang dibutuhkan untuk membuat model bisnis berlangsung.

- Kegiatan utama: Menjelaskan apa yang harus dilakukan perusahaan untuk membuat model bisnis berjalan, seperti produksi, pemecahan masalah, platform, dan aktivitas jaringan.

- Kemitraan kunci: Menjelaskan bagaimana jaringan pemasok dan mitra yang membuat model bisnis berjalan.

- Struktur biaya: Menjelaskan semua biaya yang dikeluarkan untuk mengoperasikan model bisnis.

Disamping BMC, sebuah perusahaan juga dapat melakukan analisis SWOT. Menurut Rangkuti (2018:83) matriks SWOT merupakan alat yang digunakan untuk menyusun faktorfaktor strategis perusahaan. Matriks ini dapat menggambarkan secara jelas bagaimana peluang dan ancaman eksternal yang dihadapi perusahaan dapat disesuaikan dengan kekuatan dan kelemahan yang dimilikinya.

SWOT adalah singkatan dari lingkungan Internal Strengths dan Weaknesses serta lingkungan eksternal Opportunities dan Threats yang dihadapi. Analisis SWOT selanjutnya akan membandingkan faktor lingkungan Internal terhadap lingkungan eksternal. Kombinasi analisis kekuatan, kelemahan, peluang dan ancaman (SWOT) melalui BMC merupakan cara yang efektif untuk melihat setiap komponen model bisnis secara lebih detail (Disa et al., 2017; Haryati, 2021).

Penelitian ini diharapkan dapat memberikan kontribusi terhadap eksistensi UMKM di Indonesia dan memberikan saran terkait strategi restrukturisasi model bisnis dalam membantu UMKM bertahan dalam situasi pandemi COVID-19.

\section{Metode Penelitian}

Penelitian ini menggunakan metode metode kualitatif, dengan studi literatur yang diperoleh dari beberapa sumber yakni buku dan hasil penelitian jurnal elektronik. Data yang sudah diperoleh kemudian dianalisis dengan metode analisis deskriptif. Deskripsi dari model bisnis tersebut dipaparkan dengan menggunakan tools Business Model Canvas (BMC) dan kemudian dilakukan analisis pada setiap elemen blok Business Model Canvas (BMC).

\section{Hasil dan Pembahasan}

Variabel yang digunakan dalam penelitian terdiri dari sembilan elemen BMC sebagai gambaran visual dari model bisnis yang dijalankan oleh pelaku UMKM bidang kuliner di Pekanbaru. Sembilan elemen BMC tersebut termasuk empat bidang utama bisnis yaitu pelanggan, suplai, infrastruktur, dan keberlanjutan keuangan. BMC usaha kuliner dapat ditunjukkan pada gambar sebagai berikut:

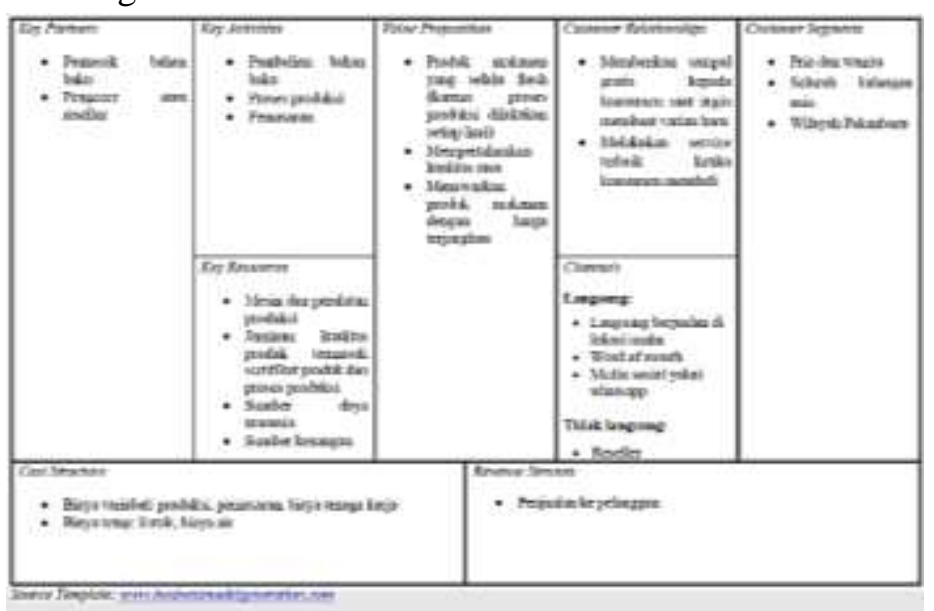

Gambar 1. BMC UMKM Bidang Kuliner di Pekanbaru

Pada Gambar 1 diatas, dapat diketahui bahwa target pasar dari usaha kuliner jenis jajanan tradisional ini adalah pria dan wanita dari berbagai jenis kalangan usia yang berada di wilayah Pekanbaru. Proposisi nilai yang ditawarkan pada 
saat ini berupa produk kue yang selalu berada dalam keadaan fresh dan memiliki harga terjangkau. Hubungan dengan pelanggan dipertahankan dengan selalu memberikan upaya dalam memberikan pelayanan kepada konsumen saat membeli kue langsung di lokasi berjualan. Saluran dari usaha ini masih menggunakan penjualan secara langsung di lokasi usaha, word of mouth, serta whatsapp. Kegiatan utama yang dilakukan berupa pengadaan bahan baku, proses produksi dan pemasaran. Kegiatan usaha ini bekerjasama dengan mitra terkait yakni pemasok bahan baku dan reseller. Struktur biaya yang digunakan adalah biaya variabel seperti produksi, pemasaran, biaya tenaga kerja, dan biaya tetap seperti biaya listrik, dan air. Penghasilan berasal dari penjualan jajanan tradisional tersebut.

Selanjutnya adalah dilakukannya analisis bisnis agar tindakan manajemen yang tepat sesuai dengan kondisi atau informasi yang diperoleh dalam pemecahan kasus UMKM bidang kuliner tersebut. Analisis kasus ini penting dilakukan dalam mengambil keputusan. Maka untuk itu sangat diperlukan pemahaman mengenai riset pasar, dan sistem pengambilan keputusan. Berikut merupakan hasil analisis IFAS EFAS dari UMKM bidang kuliner Pekanbaru:

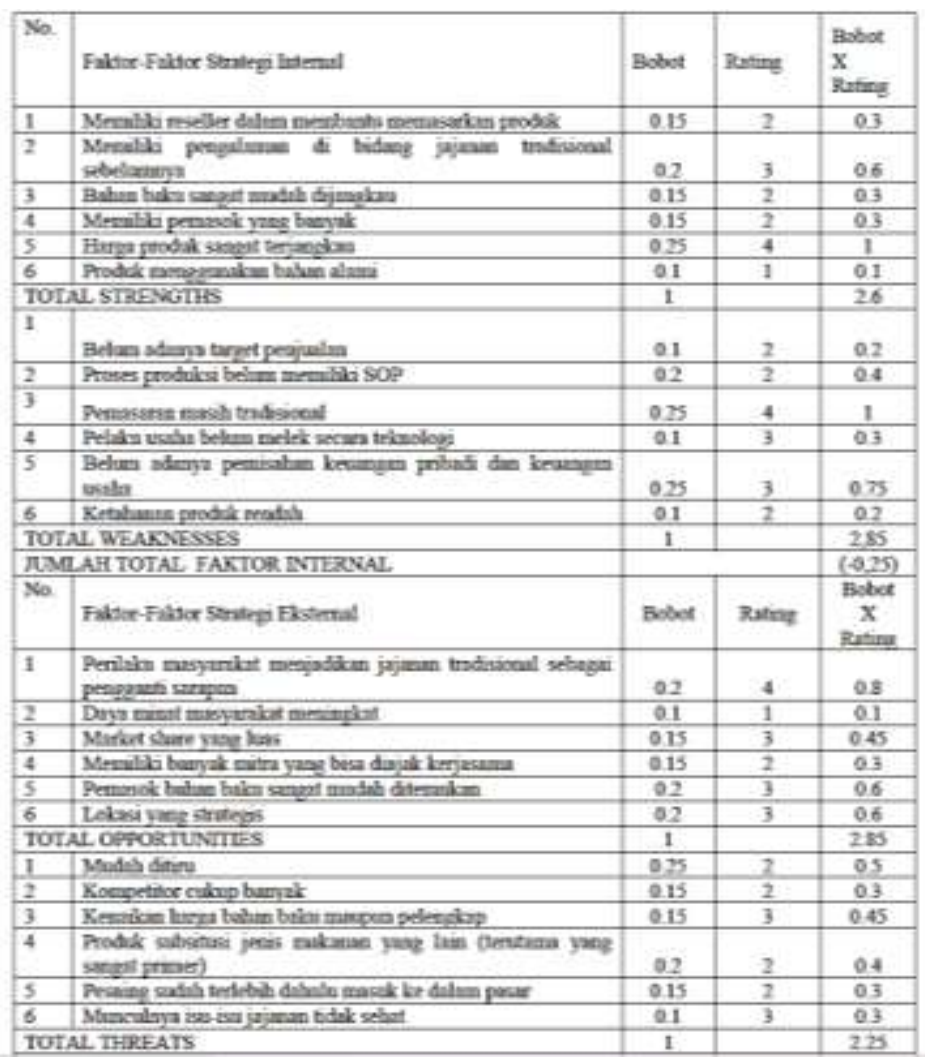

Gambar 2. IFAS EFAS UMKM Kuliner
Posisi sumbu X:

i. $\quad$ Total bobot Strengths : 2.6

ii. Total bobot Weaknesses : 2.85

iii. Posisi sumbu $X: 2.6-2.85=(-0.25)$

Posisi sumbu Y:

i. Total bobot Opportunities: 2.85

ii. Total bobot Threats: 2.25

iii. Posisi sumbu Y : 2.85-2.25 $=0.6$

Berdasarkan penghitungan analisis IFAS EFAS yang terdapat pada Gambar 2 diatas, dapat diperoleh penghitungan bahwa analisis posisi sumbu $\mathrm{X}$ dari UMKM memperoleh angka $-0,25$ dan posisi sumbu $\mathrm{Y}$ berada pada angka 0,6. Analisis ini kemudian penulis tuangkan ke dalam kuadran IFAS EFAS yang dikembangkan oleh Wheelen and Hunger menjadi ke dalam 4 kuadran sebagai berikut:

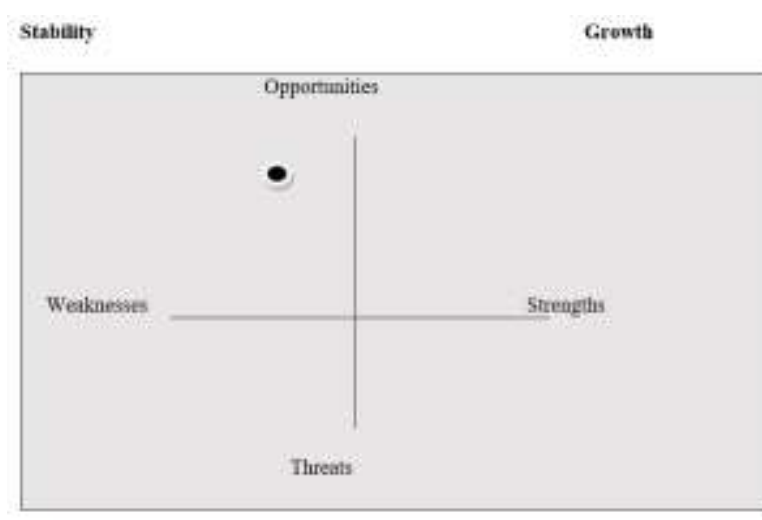

Retrenchemerst

Diversincation

Gambar 3. Kuadran IFAS \& EFAS

Gambar 3 diatas menunjukkan bahwa UMKM bidang kuliner jajanan tradisional di Pekanbaru berada pada kuadran II. Wheelen and Hunger (2012) menjelaskan bahwa perusahaan yang berada di kuadran II dianjurkan untuk memilih stability strategies. Perusahaan yang berada pada kuadran II sedang menghadapi peluang pasar yang besar, tapi disisi lain perusahaan memiliki kelemahan dalam aspek internal pada perusahaan. Lemahnya aspek internal ini dikarenakan beberapa hal dalam yang berdampak kepada perlakukan yang belum optimal dalam perusahaan. Salah satunya yakni belum adanya sistem pemasaran yang baik sehingga pemasaran saat ini saat bergantung kepada 
penjualan secara offline yakni penjualan secara langsung di lokasi berjualan. Strategi ini difokuskan untuk meminimalkan masalah internal tersebut untuk mempersiapkan potensi pasar yang besar dan memaksimalkan pemasaran untuk mampu bertahan di era COVID-19 .

\section{Strategi Restrukturisasi Model Bisnis untuk Bertahan di Era COVID-19}

Pada blok yang pertama yakni segmen pelanggan, strategi yang diterapkan dalam blok ini adalah dengan melakukan penetrasi segmen pasar baru selama pandemi dengan menjual produk penting yang sedang berkembang seperti makanan berat dan lain sebagainya.

Pada blok kedua yakni value proposition, strategi yang dapat diterapkan dalam blok ini adalah dengan melakukan perancangan value proposition yang ditawarkan seperti produk sampingan berupa makanan dan minuman yang memiliki manfaat dari Kesehatan disaat pandemic COVID-19 .

Disamping hal itu, beberapa cara secara umum yang dapat dilakukan UMKM bidang kuliner dalam merancang sebuah proposisi nilai yang baik adalah sebagai berikut:

a. Menawarkan inovasi, seperti menciptakan nilai baru, memberi sesuatu kepada pelanggan yang belum ada sebelumnya. Seperti inovasi produk dengan menambah varian baru, dan lain sebagainya.

b. Membuat produk / layanan yang memudahkan pelanggan dalam melakukan pembelian kue jajanan tradisional tersebut. Hal ini memungkinkan segmen pelanggan itu sebelumnya tidak dapat menggunakan produk/layanan, lalu setelah itu pelanggan dapat untuk mengaksesnya seperti layanan pesan antar dan lain sebagainya.

c. Meningkatkan produk atau layanan dengan menambahkan fitur yang relevan atau memodifikasi yang ada saat ini agar lebih berfungsi untuk kebutuhan tertentu

d. Memperkuat merek atau identitas yang dapat UMKM tersebut berbeda dengan pesaing lainnya.

e. Memperbaiki desain produk

f. Mengurangi risiko-resiko yang terkait dengan produk atau layanan

Pada blok ketiga, strategi yang diterapkan dalam blok saluran adalah dengan menguatkan dan memperluas pemasaran digital melalui aplikasi seluler dan media sosial, seperti Facebook, WhatsApp, Instagram. Selain itu, UMKM juga dapat mendaftarkan usahanya pada layanan mitra seperti Go-Food, Grab-Food dan lain sebagainya yang dapat memudahkan UMKM dalam menjangkau pelanggan. Disamping hal itu, UMKM juga dapat memberikan layanan yang menggunakan transaksi "cash on delivery" atau COD dalam penjualan barang sehingga konsumen lebih merasa aman ketika berbelanja. Strategi ini sejalan dengan pendekatan saluran omni channel marketing yang disarankan untuk penggunaan beberapa saluran dalam mendistribusikan barang ke pelanggan, misalnya melalui distributor, aplikasi seluler, dan penyimpanan fisik akan lebih menguntungkan daripada pendekatan saluran tunggal dan independen.

Untuk blok keempat, salah satu langkah terbaik yang dilakukan adalah fokus menata kembali pemberian layanan kepada customer. Salah satu langkah yang bisa diperluas adalah dengan menyediakan layanan pesan antar atau delivery. Strategi ini merupakan penyesuaian dari kondisi krisis COVID-19 secara tidak langsung memaksa UMKM untuk melakukan perubahan besar- besaran ke dunia online. Misalnya layanan pesan antar, free ongkir pengiriman dengan minimal pembelian tertentu dan lain sebagainya.

Pada blok kelima, strategi yang diterapkan dalam blok ini adalah meningkatkan dan memperkuat kolaborasi. Kolaborasi merupakan kunci dalam mensukseskan ketahanan bisnis, sehingga dibutuhkan kolaborasi antara bisnis itu sendiri dengan segala mitra atau pemangku kepentingan yang berhubungan dengan bisnis tersebut. Misalnya mengadakan pertemuan khusus dengan mitra-mitra terkait strategi yang tepat sebagai jawaban tantangan dalam rangka 
mencapai ketahanan bisnis di era COVID-19. Disamping hal itu, strategi yang dapat dilakukan adalah dengan bekerjasama dengan kurir ekspedisi dalam mengirimkan pesanan pelanggan selama COVID-19.

Untuk blok keenam, strategi yang bisa diterapkan dalam blok untuk mencapai operasi yang berkelanjutan adalah dengan memperpendek rantai pasokan melalui distributor sinkron terpusat, memproduksi produk baru untuk memenuhi kebutuhan pokok pelanggan saat ini yaitu makanan, produk pembersih, dan lain sebagainya. Disamping perubahan operasi yang menjadi kunci, distribusi produk yang serba digital termasuk juga menggunakan alat pembayaran digital seperti transfer bank atau e-wallet yang dapat menjadi pilihan bagi konsumen karena konsumen menghindari penggunaan uang kertas sehingga UMKM juga diharapkan dapat memastikan dan mengembangkan pilihan pembayaran transaksi sehingga memudahkan konsumen. Disamping hal itu, aktivitas yang perlu dilakukan adalah memperluas dan memperkuat pemanfaatan data. Pemanfaatan data ini tentu akan menghasilkan analisis yang lebih baik dalam pengambilan keputusan dan strategi yang tepat dalam menghadapi era COVID-19.

Pada blok ketujuh yakni sumber daya, langkah terbaik yang dapat dilakukan adalah fokus kepada sumber daya manusia itu sendiri. Hal ini bertujuan untuk memfasilitasi proses transformasi digital dalam suatu organisasi dengan cara yakni:

a. Menciptakan pola pikir yang benar dan pemahaman bersama

b. Menempatkan kepemimpinan yang tepat

c. Meluncurkanpusat keunggulan bisnis digital

d. Merumuskan strategi digital

e. Menemukan, mengembangkan dan memperoleh pengetahuan

f. Menciptakan kemampuan digital baru.

Langkah yang dapat dilakukan dalam meminimalisir struktur biaya adalah dengan melakukan analisis pemotongan biaya yang tidak perlu dan tidak menghasilkan pendapatan untuk mengamankan fungsi utama dari UMKM. Hal ini bertujuan untuk mengamankan likuiditas dan solvabilitas. Disamping hal itu, hal yang perlu dilakukan adalah dengan membuat prediksi dana dalam jangka pendek. UMKM juga dapat membuat 3 golongan cost structure yakni:

a. Pengeluaran yang memang harus dikeluarkan. Misalnya gaji karyawan terutama karyawan menengah ke bawah.

b. Pengeluaran yang bisa dinegosiasikan. Misalnya kewajiban- kewajiban kepada supplier atau bank atau pemilik gedung yang masih bisa dinegosiasikan untuk pembayarannya

c. Pemotongan biaya yang harus dilakukan dalam jangka pendek kedepan sehingga menguatkan posisi dana tunai yang dimiliki oleh UMKM tersebut. Misalnya pemotongan biaya promosi yang masih bisa dipotong dan lain sebagainya.

Pada blok kesembilan yakni sumber pendapatan, strategi yang bisa diterapkan dalam blok ini adalah meneliti kembali pendapatan yang masih memungkinkan untuk ditingkatkan dan dianalisis bersama struktur biaya. Hal ini bertujuan untuk mempertahankan kesuksesan yang dicapai dengan membuat model bisnis berkelanjutan. Perlu diperhatikan bahwa pendapatan ini tidak hanya terkait dengan harga, tetapi UMKM harus juga memperhatikan factorfaktor terkait lainnya yakni metode pembayaran, sumber daya, mitra, dan aktivitas utama dari bisnis tersebut.

\section{Kesimpulan}

Tujuan penelitian ini adalah untuk mendeskripsikan inovasi model bisnis yang dapat dilakukan oleh UMKM dalam menghadapi era COVID-19 . Penulis memanfaatkan teori yang ada dari literatur model bisnis untuk mengidentifikasi kunci komponen atau kondisi model bisnis yang berkelanjutan dalam mencapai ketahanan bisnis. Hal ini bertujuan untuk memberikan saran sebagai panduan bagi perusahaan dalam merancang model 
bisnis dalam menghadapi COVID-19 .

\section{Daftar Pustaka}

Acter, T., Uddin, N., Das, J., Akhter, A., Choudhury, T. R., \& Kim, S. (2020). Evolution of severe acute respiratory syndrome coronavirus 2 (SARS-CoV-2) as coronavirus disease 2019 (COVID-19) pandemic: A global health emergency. Science of the Total Environment, 138996.

Alexander, O., \& Yves, P. (2010). Business Model Generation. Canada, John Wiley \& Sons, Inc.

Anzai, A., Kobayashi, T., Linton, N. M., Kinoshita, R., Hayashi, K., Suzuki, A \& Nishiura, H. (2020). Assessing the impact of reduced travel on exportation dynamics of novel coronavirus infection (COVID- 19). Journal of clinical medicine, 9(2), 601.

Baden-Fuller, C., \& Morgan, M. S. (2010). Business models as models. Long range planning, 43(2-3), 156-171.

Baghiu, M. C. (2020). Analysis of Business Model Innovation in Post-Covid Economy: Determinants for Success. Journal of Public Administration, Finance \& Law, 17, 7-24.

Casalino, N., Żuchowski, I., Labrinos, N., Munoz Nieto, Á. L., \& Martín, J. A. (2019). Digital Strategies and Organizational Performances of SMEs in the Age of Coronavirus: Balancing Digital Transformation with An Effective Business Resilience. Queen Mary School of Law Legal Studies Research Paper Forthcoming.

Chauhan, V., Galwankar, S., Arquilla, B., Garg, M., Di Somma, S., El-Menyar, A., ... \& Stawicki, S. P. (2020). Novel coronavirus (COVID-19): Leveraging telemedicine to optimize care while minimizing exposures and viral transmission. Journal of emergencies, trauma, and shock, 13(1), 20.

Coombs, W. T. (2007). Protecting organization reputations during a crisis: The development and application of situational crisis communication theory. Corporate reputation review, 10(3), 163-176.

Disa, A. A., Nurmalina, R., \& Syuaib, M. F. (2017). Analysis of Business Model Development of Honey Products Using Business Model Canvas Approach. International Journal of Science and Research, 262-267.

Fabeil, N. F., Pazim, K. H., \& Langgat, J. (2020). The impact of COVID-19 pandemic crisis on micro- enterprises: Entrepreneurs' perspective on business continuity and recovery strategy. Journal of Economics and Business, 3(2).

Fernandes, N. (2020). Economic Effects of Coronavirus Outbreak (COVID-19) on the World Economy (SSRN Scholarly Paper ID 3557504). Social Science Research Network. https://doi.org/10.2139/ssrn, 3557504.

Fielt, E. (2013). Conceptualising business models: Definitions, frameworks and classifications. Journal of Business Models, 1(1), 85-105.

Fitriasari, F. (2020). How do Small and Medium Enterprise (SME) survive the COVID-19 outbreak?. Jurnal Inovasi Ekonomi, 5(02).

Foss, N. J., \& Saebi, T. (Eds.). (2015). Business model innovation: The organizational dimension. OUP Oxford.

Gorissen, L., Vrancken, K., \& Manshoven, S. (2016). Transition thinking and business model innovation-towards a transformative business model and new role for the reuse centers of Limburg, Belgium. Sustainability, 8(2), 112.

Hadiwardoyo, W. (2020). Kerugian Ekonomi Nasional Akibat Pandemi COVID-19. Baskara: Journal of Business and Entrepreneurship, 2(2), 83-92.

Haryati, N. (2021, April). Business model analysis of mushroom agroindustry and its sustainable development strategy in COVID-19 pandemic. In IOP Conference Series: Earth and Environmental Science (Vol. 733, No. 1, p. 012125). IOP 
Publishing.

Hedman, J., \& Kalling, T. (2003). The business model concept: theoretical underpinnings and empirical illustrations. European journal of information systems, 12(1), 4959.

Inoue, H., \& Todo, Y. (2020). The propagation of economic impacts through supply chains: The case of a mega-city lockdown to prevent the spread of COVID-19. PloS one, 15(9), e0239251.

Jaques, T. (2007). Issue management and crisis management: An integrated, non-linear, relational construct. Public relations review, 33(2), 147-157.

Johnson, M. W., \& Lafley, A. G. (2010). Seizing the white space: Business model innovation for growth and renewal. Harvard Business Press.

Kuckertz, A., Brändle, L., Gaudig, A., Hinderer, S., Reyes, C. A. M., Prochotta, A., ... \& Berger, E. S. (2020). Startups in times of crisis-A rapid response to the COVID-19 pandemic. Journal of Business Venturing Insights, 13, e00169.

Milzam, M., Mahardika, A., \& Amalia, R. (2020). Corona virus pandemic impact on sales revenue of micro small and medium enterprises (MSMEs) in Pekalongan City, Indonesia. Journal of Vocational Studies on Applied Research, 2(1).

Morris, L. (2010). Business model innovation the strategy of business breakthroughs. International Journal of Innovation Science.

Ojasalo, J., \& Ojasalo, K. (2018). Service logic business model canvas. Journal of research in marketing and entrepreneurship.

Ozamiz-Etxebarria, N., Dosil-Santamaria, M., Picaza-Gorrochategui, M., \& IdoiagaMondragon, N. (2020). Stress, anxiety, and depression levels in the initial stage of the COVID-19 outbreak in a population sample in the northern Spain. Cadernos de saude publica, 36, e00054020.
Park, S. E. (2020). Epidemiology, virology, and clinical features of severe acute respiratory syndrome-coronavirus-2 (SARS-CoV-2; Coronavirus Disease- 19). Clinical and experimental pediatrics, 63(4), 119.

Pedersen, C. L., Ritter, T., \& Di Benedetto, C. A. (2020). Managing through a crisis: Managerial implications for business-tobusiness firms. Industrial Marketing Management, 88, 314.

Peeri, N. C., Shrestha, N., Rahman, M. S. Zaki, R., Tan, Z., Bibi, S., ... \& Haque, U. (2020). The SARS, MERS and novel coronavirus (COVID-19 ) epidemics, the newest and biggest global health threats: what lessons have we learned?. International journal of epidemiology, 49(3), 717-726.

Qiu, W., Rutherford, S., Mao, A., \& Chu, C. (2017). The pandemic and its impacts. Health, culture and society, 9, 1-11.

Rangkuti, R. (2018). Teknik Membedah Kasus Bisnis Analisis SWOT. PT. Gramedia Pustaka Utama.

Ritter, T., \& Pedersen, C. L. (2020). Analyzing the impact of the coronavirus crisis on business models. Industrial Marketing Management, 88, 214-224.

Sułkowski，Ł. (2020). COVID-19 pandemic; recession, virtual revolution leading to deglobalization?. Journal of Intercultural Management, 12(1), 1-11.

Williams, T. A., Gruber, D. A., Sutcliffe, K. M., Shepherd, D. A., \& Zhao, E. Y. (2017). Organizational response to adversity: Fusing crisis management and resilience research streams. Academy of Management Annals, 11(2), 733-769.

Zhou, L., Chen, E., Bao, C., Xiang, N., Wu, J., $\mathrm{Wu}$, S., ... \& Li, Q. (2018). Clusters of human infection and human-to- human transmission of avian influenza A (H7N9) virus, 2013-2017. Emerging infectious diseases, 24(2), 397. 